\title{
SOSIALISASI PENGHIJAUAN LINGKUNGAN DENGAN TANAMAN HIDROPONIK DI RPTRA AMANAH BUNDA TANJUNG DUREN SELATAN
}

\author{
Ferdinand Fassa ${ }^{1}$, Sani Heryanto ${ }^{2}$ \\ ${ }^{1}$ Universitas Agung Podomoro \\ ${ }^{2}$ Univerrsitas Agung Podomoro
}

ferdinand.fassa@podomorouniversity.ac.id, sani.heryanto@ podomorouniversity.ac.id

\begin{abstract}
Abstrak
Terbatasnya ruang terbuka hijau (RTH) di kota Jakarta yang disebabkan oleh pembangunan yang terus meningkat secara masif mengakibatkan perubahan lingkungan fisik sehingga menurunkan kualitas lingkungan. Ruang terbuka hijau diharapkan memberikan fungsi dasar seperti fungsi bio-ekologi, sosial dan ekomomi. Undang-undang Nomor 26 tahun 2007 tentang Penataan Ruang mewajibkan setiap provinsi memiliki 30\% RTH. Dalam kenyataannya ketersediaan RTH sebesar 30\% sulit untuk diwujudkan di DKI Jakarta dengan berbagai macam masalahnya. Dengan kondisi ini maka diperlukan suatu cara untuk "menghijaukan" wilayah DKI Jakarta baik itu di kawasan perumahan maupun wilayah dengan lahan terbuka yang terbatas. Salah satu cara untuk menghijaukan lingkungan dengan lahan yang terbatas dengan cara hidroponik. Media tanam hidroponik adalah cara membudidayakan tanaman dengan memanfaatkan air tanpa menggunakan banyak tanah sebagai media tanamnya. Metode hidroponik merupakan salah satu cara mengatasi keterbatasan lahan hijau, yang dalam perawatannya, tanaman hidroponik memerlukan ketelitian yang lebih. Jalur distribusi air pada hidroponik juga harus selalu diperhatikan dengan cara menghindari air hujan yang jatuh ketanaman dikarenakan mengandung asam yang membuat tanaman menjadi kekurangan nutrisi sehingga batang bisa busuk karena air yang menggenang terlalu tinggi. Sosialisasi penanaman dengan metode Hidroponik di lingkungan RPTRA Amanah Bunda ini bertujuan untuk menambah pengetahuan masyarakat dan pengelola tentang penghijauan dengan metode Hidroponik dan memotivasi masyarakat untuk peduli terhadap penghijauan lingkungan.

Kata Kunci : Ruang Terbuka Hijau, keterbatasan Lahan, Metode Hidroponik, RPTRA Amanah Bunda
\end{abstract}

\section{PENDAHULUAN}

Ruang Terbuka Hijau (RTH) secara fungsi memiliki beberapa aspek yaitu fungsi ekologis, fungsi arsitektur dan fungsi ekonomi (Supriyatno, 2009). Adapun fungsi ekologis adalah ruang terbuka hijau dapat menurunkan suhu udara, berikutnya dapat mengurangi polusi udara, mencegah banjir dan meningkatkan kualitas air tanah. Fungsi sosial budaya, dengan adanya ruang terbuka dapat memberikan ruang untuk berinteraksi diantara masyarakat, sebagai sarana rekreasi dan sebagai tanda kota berbudaya. Dilihat dari fungsi arsitektur,

Lingkungan dan Kebencanaan 
ruang terbuka dapat meningkatkan keindahan dan kenyamanan kota melalui keberadaan taman kota. Jikaditinjau dari fungsi ekonomi, apabila ruang terbuka hijau ini dikelola dengan baik dapat mengundang penghuni kota hadir berekreasi dan membangkitkan sektor ekonomi di sekitarnya seperti jasa parkir, warung, tempat makan dan sebagainya. Namun pada kenyataanya, ruang terbuka hijau yang dibutuhkan jauh dari ideal. Sehingga menuntut masyarakat untuk berperan aktif membantu pemerintah dalam mewujudkan kondisi ini.

Salah satu cara dalam meningkatkan fungsi ekologis yaitu dengan berkreasi untuk menambah penghijauan di wilayah masing-masing dengan tanaman hijau. Tanaman hijau memiliki banyak manfaat bagi manusia, beberapa diantaranya adalah sebagai obat, sumber makanan, penyedia oksigen, dan lain-lain. Kelurahan Tanjung Duren Selatan merupakan salah satu wilayah padat dengan luas 137 ha dan dihuni 21301 jiwa (Jakarta.go.id, 2017). Jika dilihat wilayah yang ada, kawasan ini termasuk kawasan padat penduduk dengan kondisi ditiap rumahnya sangat jarang ruang terbuka hijau. Hal ini dikarenakan wilayah tersebut termasuk wilayah komersil yang terletak di pusat kota. Sehingga, penghijauan bagi masyarakat bukan menjadi prioritas. Dengan kondisi kota Jakarta yang padat penduduk dan udara yang sudah tercemar polusi penghijauan sangatlah dibutuhkan. Kota Jakarta butuh tanah resapan yang cukup dan udara yang segar. Maka dari itu, penghijauan seharusnya memiliki peran yang penting. Penanaman 1 pohon akan sangat membantu untuk menghijaukan kota Jakarta yang bisa terbilang cukup gersang. Karena hal tersebut, pemerintah dan beberapa organisasi telah mengusahakan beberapa upaya untuk menghijaukan kota Jakarta dalam bentuk peraturan daerah maupun gerakan lain seperti penanaman 1000 pohon atau membangun komunitas yang memiliki peran dalam penghijauan di Jakarta. Salah satu program pemerintah kota Jakarta dalam mengatasi permasalahan kurangnya lahan hijau di Jakarta adalah dengan mendirikan sebuah ruang publik bernama Ruang Publik Terbuka Ramah Anak (RPTRA).

RPTRA adalah bangunan yang didirikan oleh pemerintah DKI Jakarta sebagai sarana bagi masyarakat sekitar untuk melakukan kegiatankegiatan positif. Pemerintah menyediakan sebuah lahan dan bangunan kecil dimana banyak anak-anak yang datang untuk melakukan kegiatan seperti belajar, bermain dan olahraga. Tidak hanya anakanak, RPTRA juga banyak dikunjungi oleh para orangtua untuk melakukan senam atau hanya berkumpul. Tetapi, salah satu kegiatan di RPTRA yang mendukung kota Jakarta menjadi lebih hijau adalah program penanaman dan pemeliharaan tanaman obat. Program penanaman dan pemeliharaan tersebut dilakukan oleh pengelola RPTRA yang telah ditunjuk untuk menangani bidang penghijauan di RPTRA. Namun, berdasarkan observasi dilapangan, didapati bahwa kebanyakan dari para pengelola yang bertugas untuk mengurus tanaman di RPTRA ini, belajar sendiri bagaimana cara menanam tanaman tersebut (otodidak), dan masih banyak diantara pengelola yang kesulitan dalam menjalankan program penanaman dan pemeliharaan tanaman ini karena kurangnya pengetahuan tentang cara menanam tanaman tersebut. Hal ini sangat disayangkan, karena kurangnya pengetahuan tentang tanaman cukup menjadi kendala dalam menjalani program penghijauan ini. Selain itu, ketika beberapa masalah terjadi dalam proses pemeliharaan tanaman khususnya pada media tanaman hidroponik, pengelola kesulitan untuk mencari solusi dari masalah tersebut dan menerka-nerka bagaimana cara menyelesaikannya.

Menyadari bahwa para pengelola RPTRA membutuhkan bimbingan atau ilmu tentang tanaman, maka dibutuhkan suatu sosialisasi dalam bentuk pelatihan guna menambah wawasan para pengelola

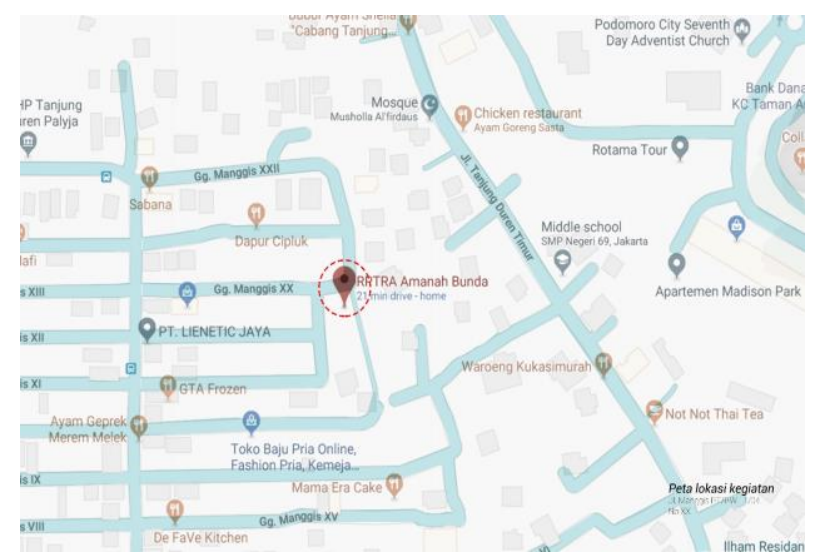

RPTRA dalam hal ini RPTRA yang dekat dengan Universitas Agung Podomoro, yaitu RPTRA 
Amanah Bunda Di wilayah Tanjung Duren Selatan (Gambar 1).

Gambar 1. Lokasi kegiatan PKM

Sosialisasi mengenai penanaman dan pemeliharaan tanaman dengan metode hidroponik dengan baik dan benar diharapkan bisa menjadi bekal bagi para pengelola untuk menjalankan program penghijauan di RPTRA.

RPTRA Amanah Bunda terletak $\pm 1 \mathrm{~km}$ dari kantor Keluarahan Tanjung Duren Selatan. RPTRA ini tergolong sebagai salah satu RPTRA di Wilayah Jakarta Barat yang banyak memiliki program kerja salah satunya penanaman tanaman obat yang memiliki manfaat untuk warga sekitar. Biasanya, masyarakat setempat yang membutuhkan obat untuk keluarganya, akan datang ke RPTRA Amanah Bunda untuk mencari tanaman obat tersebut. Bukan hanya tanaman obat, RPTRA Amanah Bunda juga menanam beberapa tanaman sayur.

Lahan tanah di RPTRA Amanah Bunda cukup terbatas, namun tidak menyurutkan pengelola untuk menanam berbagai jenis tanaman obat dan sayur. Beberapa jenis tanamannya antara lain kumis kucing, pecah beling, binahong, lengkuas, mahkota dewa, dan masih banyak jenis tanaman lainnya.

Untuk variasi tanaman, RPTRA Amanah Bunda sudah tergolong baik. Selain lahan, RPTRA Amanah Bunda memiliki 3 media tanam hidroponik yang sedang dijalani. Ada 1 media tanam hidroponik yang ditanami oleh tanaman hias. 1 media tanam hidroponik lain menanam tanaman sayur, yaitu pakcoy dan satu media tanaman yang digunakan untuk meletakkan tanah dan beberapa tanaman sayur lainnya.

Menurut pengelola, tanaman hidroponik memiliki kekurangan yang membutuhkan perhatian khusus dari segi penyiraman dan perawatan. Salah satu media hidroponik (media tanam yang ditanam tanaman hias) juga membutuhkan modifikasi karena adanya kerusakan, yaitu selang yang lepas sehingga air tidak mengalir dengan baik sehingga air tersebut tergenang dan menjadi sumber jentik-jentik nyamuk. Kondisi 2 media tanam hidroponik lainnya tergolong baik dan belum membutuhkan perbaikan.
Tetapi, jenis media tanam hidroponik membutuhkan penanganan. Pengelola RPTRA mengatakan bahwa akan lebih baik jika variasi tanaman sayur dan obat di RPTRA bertambah. Semua penghijauan yang terjadi di RPTRA Amanah Bunda ditangani oleh satu orang pengelola. Untuk menjalankan tugasnya, pengelola RPTRA Amanah Bunda bidang penghijauan belajar secara otodidak tentang cara penanaman, perawatan dan manfaat dari semua tanaman yang ada. Terkadang pengelola kesulitan dalam melakukan tugasnya karena kurangnya sosialisasi tanaman dari pemerintah kepada para pengelola RPTRA terbilang sangat kurang sehingga mereka harus mempelajarinya sendiri tanpa bantuan dari ahli.

Dari Latar belakang diatas maka dapat dibuat beberapa pertanyaan masalah yaitu: 1) Bagaimana cara agar pengelola RPTRA Amanah Bunda bidang penghijauan mendapat pengetahuan lebih tentang tanaman hidroponik? 2) Bagaimana meningkatkan kualitas media tanam hidroponik yang sudah ada di RPTRA Amanah Bunda? 3) Bibit tanaman apa yang memiliki banyak manfaat bagi RPTRA Amanah Bunda?

\section{METODE}

Sasaran kegiatan sosialisasi ini adalah pengelola RPTRA di lingkungan kecamatan Grogol dan masyarakat sekitar kelurahan Tanjung Duren Selatan, Jakarta Barat. Metode kegiatan yang akan dilakukan pada pengabdian kepada masyarakat ini adalah metode ceramah, diskusi dan demonstrasi praktik langsung di lapangan mengenai pemanfaatan lahan melalui penerapan konsep tanaman hidroponik. Pada pelaksanaan kegaitan sosialisasi ini ada beberapa tahapan kegiatan yang terlihat pada gambar 2 dibawah ini.

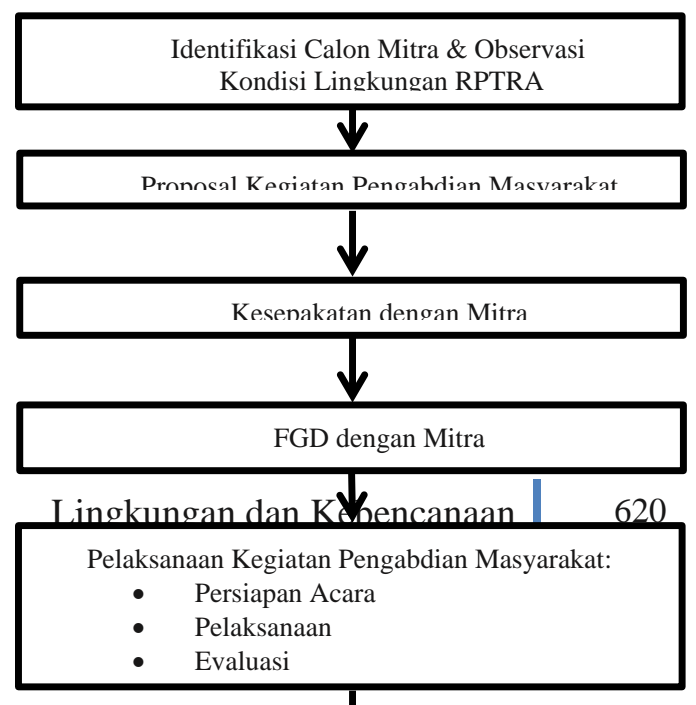


Gambar 2. Bagan Alir Kegiatan Sosialisasi

Berdasarkan gambar 2, tahapan pertama adalah: 1) Tim Pengabdian Kepada Masyarakat (PKM) mengunjungi RPTRA Amanah Bunda dan melakukan diskusi dengan pengelola terkait dengan pemetaan, identifikasi lingkungan dan jumlah peserta dari pengelola RPTRA (Gambar 3). Selain mendata jumlah peserta, tim pkm berdiskusi tentang penentuan hari dan jam pelaksanaan acara sosialisasi.

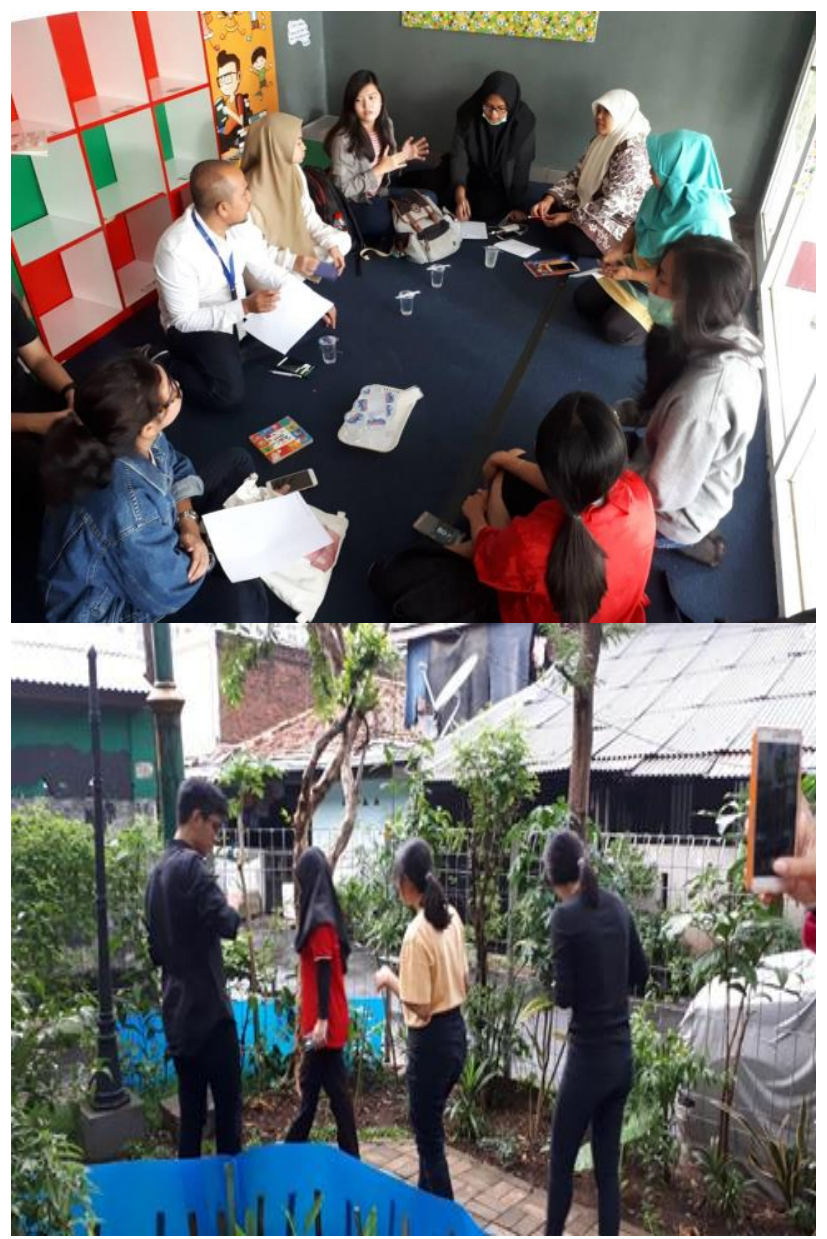

Gambar 3. Identifikasi dan Observasi Lapangan
2) Pembuatan surat izin atau persetujuan yang akan diberikan kepada kelurahan sebagai pengumuman adanya acara di RPTRA Amanah Bunda. 3) Pembuatan proposal acara. 4) Membeli alat dan bahan untuk memperbaiki media tanam hidroponik. 5) Menghitung jumlah anggaran biaya. 6) Mempersiapkan goodie bag yang akan dibagikan saat acara sosialisasi, dengan metode: a) Penanaman: benih jahe akan ditanam di media tanah yang sudah dimasukkan ke dalam aqua gelas kecil. b) Pemeliharaan sementara: benih disiram dan diletakkan di tempat yang terkena sinar matahari agar dapat tumbuh dengan baik. Hal ini dilakukan secara berkala. Bibit kemungkinan akan diberi nutrisi. c) Tunas sudah tumbuh, aqua gelas berisi tunas akan dibungkus dengan packaging yang ada. d) Bibit siap diberikan sebagai reward kepada peserta yang hadir pada acara sosialisasi.

7) Mempersiapkan slide presentasi untuk presentasi pada acara sosialisasi. yang berisi: a) Penjelasan tentang pengertian tanaman hidroponik. b) Cara menanam tanaman dengan metode hidroponik. c) Inovasi dan sistem/cara kerja tanaman hidroponik. d) Jenis tanaman yang dapat tumbuh di media tanam hidroponik.

Setelah proses persiapan selesai, kemudian dilakukan pelaksanaan kegiatan mengenai proses pembuatan media tanam hidroponik. Pada proses ini Tim PKM membagi kedalam kebeberapa tahapan, yaitu: 1) Tim PKM meninjau kembali ke RPTRA Amanah Bunda untuk melihat lokasi dan kebutuhan alat dan material media hidroponik tersebut. 2) Pipa media tanam hidroponik yang digunakan dalam sosialisasi ini menggunakan lapisan mika. Lapisan mika tersebut akan digulung dan diikat dengan kawat besi agar kokoh.

3) Setelah itu, lapisan mika akan dilubangi lebih besar sehingga media tanamnya lebih luas. 4) Selain penggantian pipa, saluran penghubung pipa (berada di ujung pipa, menyambung dengan selang) yang tadinya disambung ke bagian tengah penutup pipa, akan dipindahkan sedikit ke bawah agar air dapat mengalir dengan lebih cepat. 5) Selang-selang yang sudah lepas akan diganti dengan saluran pipa kecil. 6) Lapisan mika disambung dengan penutup pipa dan saluran pipa kecil. 7) Memindahkan tanaman yang ada di pipa lama ke lapisan mika dan menanam bibit tanaman baru. 8) Media tanam hidroponik baru yang

Lingkungan dan Kebencanaan 
sudah diisi tanaman akan diletakkan kembali ke rak besi yang ada.

Pada saat acara sosialisasi Tanaman Hidroponik, ada beberapa rencana yang perlu disiapkan yaitu: 1) Sebelum acara dimulai, Tim PKM mempersiapkan lokasi acara dengan mengatur kursi dan dibantu oleh para pengelola. 2) Tim PKM mempersiapkan bahan presentasi dengan proyektor. 3) Kemudian tim mempersiapkan goodie bag yang akan dibagikan di akhir acara. 4) Tim mempersiapkan konsumsi yang akan dibagikan sebelum acara dimulai. 5) Tim mempersiapkan daftar hadir peserta yang datang ke acara. 6) Saat peserta sosialisasi datang ke lokasi, anggota mendata daftar hadir peserta dan memberikan konsumsi kepada peserta. 7) Pembukaan acara oleh ketua untuk menyampaikan maksud dan tujuan terselenggaranya acara sosialisasi tanaman hidroponik. 8) Acara dimulai, sosialisasi dilakukan dengan presentasi slide tentang pembuatan media tanaman hidroponik, mekanisme penanaman dan perawatannya. 9) Setelah sesi foto selesai, dilakukan survey terkait kegiatan ini dan lembar surveynya ditukar dengan bibit tanaman dalam bentuk goodie bag yaitu bibit tanaman jahe untuk masing-masing peserta yang telah hadir. Setelah acara selesai, Tim PKM membersihkan lokasi acara dan memberi ucapan terimakasih kepada pengelola RPTRA Amanah Bunda atas bantuannya selama proses persiapan dan pelaksanaan acara.

\section{HASIL DAN PEMBAHASAN}

1) Kegiatan Sosialiasi, kelompok pengelola RPTRA dan masyarakat dilingkungan kelurahan Tanjung Duren Selatan sebelumnya telah mengetahui tentang konsep pemanfaatan lahan yang terbatas, namun dalam pelaksanaannya masih memiliki beberapa kendala. Permasalahan yang umum dijumpai dalam pemanfaatan lahan adalah masalah media tanam dengan Hidroponik. Kendala yang dihadapi adalah adanya genangan pada pipa sebagai media tanam sehingga pertumbuhan tanaman tidak optimal. 2) Setelah mendapatkan surta persetujuan Mitra RPTRA dan Kelurahan Tanjung Duren Selatan, makan kegiatan selanjutnya yang dilakukan adalah pelaksanaan sosialisasi penghijauan dengan media tanam Hidroponik.
Kegiatan dilaksanakan pada tanggal 3 Mei 2019 yang dibuka oleh Lurah Tanjung Duren Selatan Bapak Halimi S.IP di tempat RPTRA Amanah Bunda. Kegiatan ini juga dihadiri oleh kelompok pengelola RPTRA dan ibu-ibu rumah tangga diwilayah Kelurahan Tanjung Duren Selatan. Antusiasme peserta akan materi yang diberikan terlihat jelas sebagaimana ditunjukkan pada Gambar 4 dan 5 berikut.

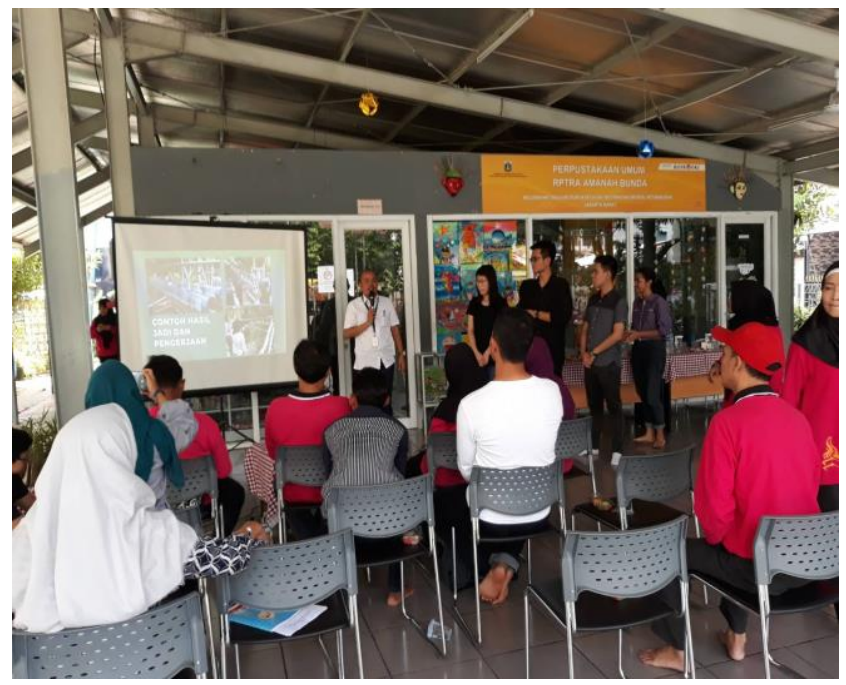

Gambar 4. Sambutan Ketua Tim Pelaksana

Pada gambar 3 terlihat kondisi dimana ketua Tim Pelaksana kegiatan sosialisasi membuka dan memperkenalkan tujuan dari kegiatan ini. Selain itu ketua tim memperkenalkan anggota tim pengabdian masyarakat yang terdiri dari dosen dan mahasiswa. Pada gambar 4, anggota tim menjelaskan proses pembuatan media tanam yang terbuat dari beberapa material seperti: plastkc mika, pipa L, kawat, lem tembak, gelas plastik air mineral.

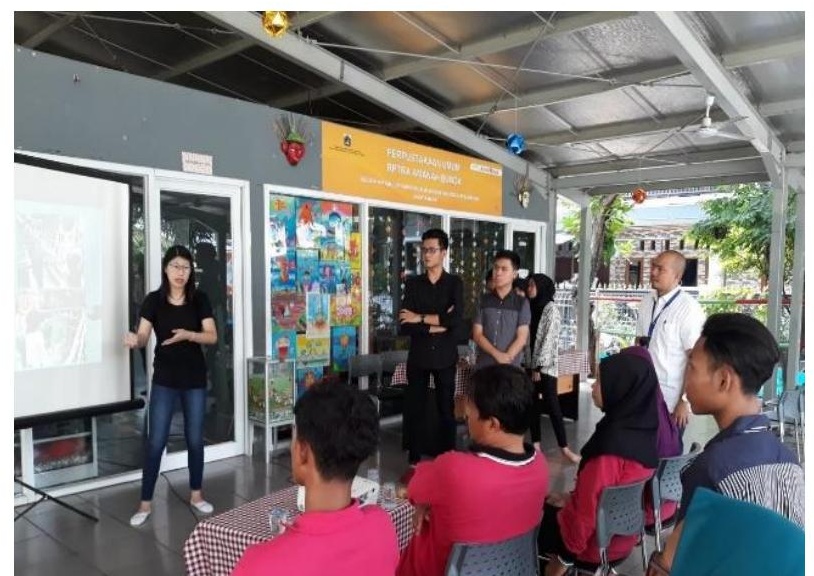


Gambar 5. Penjelasan Sosialisasi Media Tanam

Sedangkan pada gambar 6 dapat dilihat tim pengabdian masyarakat mendemontrasikan hasil pembuatan media tanam hidroponik didepan peserta. Pada tahap ini peserta sangat antusias mendengarkan tahapan demi tahapan yang disampaikan oleh tim pengabdian masyarakat.

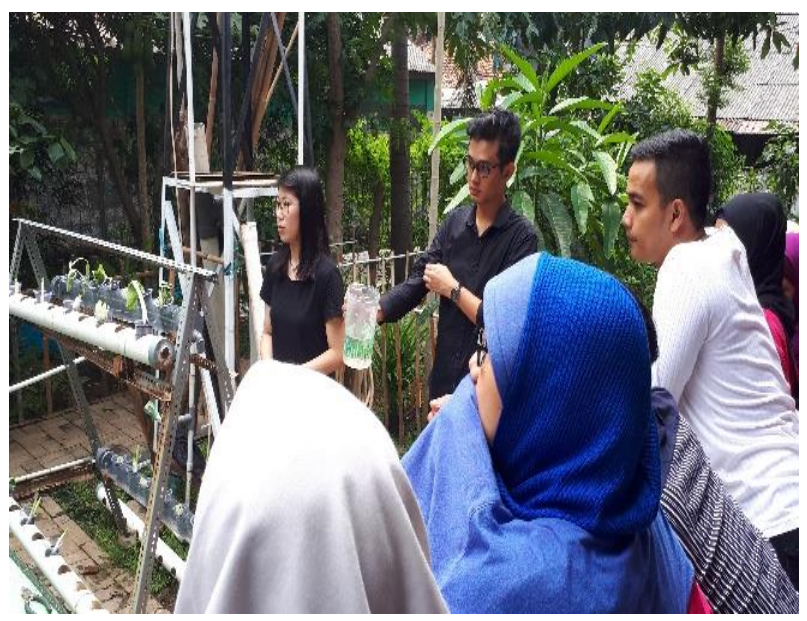

Gambar 6. Demonstrasi media Media Tanam

2) Kendala dan Solusi, saat kegiatan Sosialisasi, pada prosesnya terdapat beberapa kendala yang terjadi baik tahapan persiapan hingga tahapan pelaksanaan. Kendala pertama yaitu aaat dalam perjalanan dan saat pemasangan, 2 buah media tanam hidroponik yang telah dirakit tersenggol dan pecah. Selain itu, panjang dari media hidroponik tidak sesuai dengan rak. Solusi yang dibuat yaitu tim menggunakan 2 pipa paralon media hidroponik yang lama dengan 2 media hidroponik mika.
Kendala berikutnya yaitu jumlah peserta yang kami kira targetkan 18 orang, ternyata yang datang saat acara hanya sekitar 12 orang saja namun acara tetap berlangsung dengan baik, karena peserta cukup aktif dalam acara, suasana acara tetap terasa meriah. Ada beberapa saran dan masukan dari para peserta mengenai media hidroponik yang kami rancang dan saran ini kami gunakan untuk perbaikan kedepan. kendala berikutnya adalah dari aspek biaya yaitu rencana biaya yang dikeluarkan adalah Rp. 750.000 untuk acara ini, dimana Jumlah biaya tersebut (Rp. 750.000) sudah mencakup biaya konsumsi, media tanam, bibit tanaman, goodies bag, dan kebutuhan tambahan lainnya. Namun realisasinya Biaya yang dikeluarkan adalah Rp. 770.000, dimana terjadi over budget sebesar Rp. 20.000 karena biaya bibit tanaman yang tidak sesuai dengan perkiraan harga. Bibit tanaman yang dibeli pun ada 3 macam yang menyebabkan variasi harga. Selain itu, ongkos kirim bisa jadi menjadi salah satu faktor over budget.

Kendala yang lain terkait dengan proses pengadaan bibit dan media tanam dibeli melalui online shop. Jumlah peserta awal diperkirakan 15 orang saja sehingga bibit untuk goodie bag dan konsumsi disediakan untuk 15 orang. Sedangkan material media hidroponik dan pembungkus goodie bag dibeli langsung di toko oleh salah satu anggota kelompok. Konsumsi juga diurus oleh salah satu anggota kelompok dan dipesan langsung ke penjualnya. Aqua gelas sebagai konsumsi dibeli langsung di toko dan dari perkiraan, hanya membutuhkan 1 dus saja.

Media hidroponik dirancang dan dirakit bersama sama oleh semua anggota kelompok. Jumlah media hidroponik ada 4 buah yang bisa disambung. Namun pada pelaksanaannya bibit dan media tanam sempat sulit dicari di online shop, maka ada beberapa bibit tanaman yang harus dibeli langsung di toko. Tetapi, media tanam dan bibit jahe dapat dibeli di online shop. Jumlah goodie bag dan konsumsi yang tadinya hanya untuk 15 orang, harus ditambah karena jumlah peserta yang ternyata bertambah. Jumlah media hidroponik yang dirakit tetap 4 buah.

3) Indikator Keberhasilan, indikator keberhasilan sosisalisasi Penghijaun lingkungan dengan metode Hidroponik dilakukan dengan cara yaitu dengan memberikan sesi tanya jawab yang di

Lingkungan dan Kebencanaan 
tutup dengan pemberian lembar pertanyaan dalam bentuk kueisoner. Pertanyaan tersebut dengan membandingkan pengetahuan dan pemahaman peserta sebelum dan sesudah mengikuti kegiatan. Secara umum didapat bahwa kegiatan sosialisasi ini telah meningkatkan pengetahuan peserta mengenai pemanfaatan lahan terbatas dengan menerapkan Media tanam Hidroponik di lingkungan RPTRA Amanah Bunda. Selain itu saat sesi tanya jawab peserta memberikan tanggapan bahwa metode ini dapat membantu untuk menanam tanaman seperti tanaman obat maupun sayur yang nantinya dapat digunakan oleh peserta dalam memenuhi kebutuhan keluarga.

Indikator keberhasilan dari kegiatan ini dapat dilihat pada hasil kuesioner yang tersaji pada gambar 6 dan gambar 7. Pada gambar ini terlihat kriteria dan indikator keberhasilan pelaksanaan dari aspek materi dan aspek fasilitator yang diberikan pada kegiatan pengabdian ini.

Adapun skala penilian mengunakan likert yang terdiri dari skala 1 s.d 5 (dimana; 1: sangat kurang, 2: kurang, 3: cukup, 4: memuaskan, 5: sangat memuaskan). Setelah diolah, didapat bahwa sistematika penyampaian materi berada di angka 3.93 dari 5. Sedangkan dari aspek cara penyampaian dan penguasan materi juga berada diangka 3.80 dan 3.60 (gambar 6).

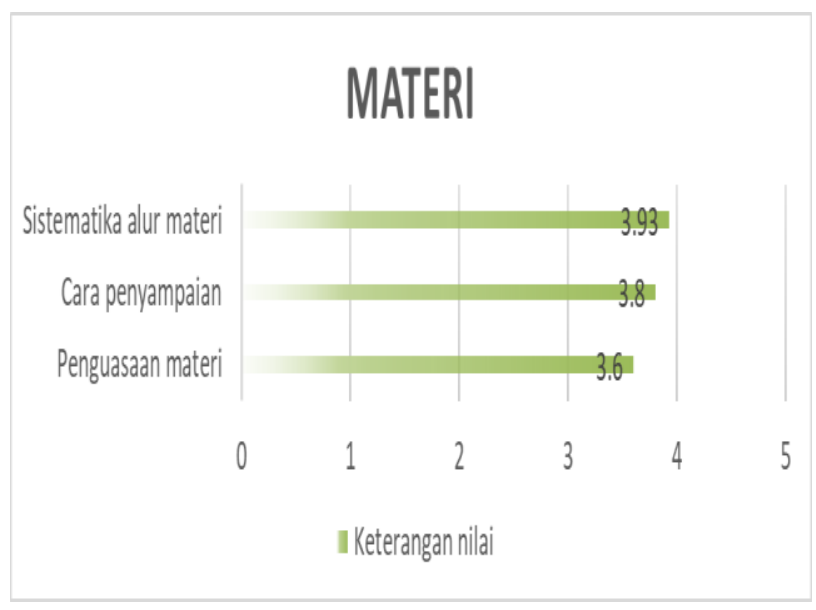

Gambar 6. Indikator Keberhasilan

Sedangkan dari aspek fasilitator, didapat bahwa indikator seperti penampilan fasilitator, kedekatan fasilitator dengan peserta dan tingkat partisipatif berada diangka diatas 4 yang artinya kegiatan ini dianggap sangat memuaskan oleh peserta. Sedangkan Sistematika alur materi, cara penyampaian dan penguasan materi berada diangka diatas 3.5 yang artinya sudah cukup memuaskan

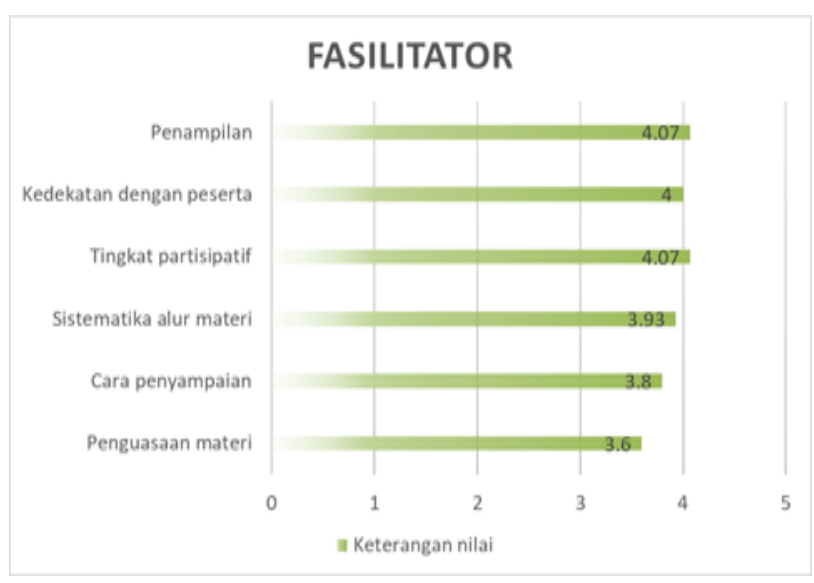

\section{KESIMPULAN}

Berdasarkan survey dari kegiatan PKM ini dapat diambil beberapa kesimpulan, yaitu: 1) Kegiatan sosialisasi Penghijauan lingkungan dengan Metode Hidroponik di wilayah lahan terbuka yang terbatas telah memberikan pengetahuan tambahan kepada pengelola dan masyarakat dilingkungan RPTRA Amanah Bunda. 2) Perlu upaya tindak lanjut agar kegiatan sosialisasi ini bisa dilakukan di lingkungan RPTRA lainnya sehingga pengetahuan terhadap penghijauan dengan lahan terbatas dapat lebih luas lagi.

\section{UCAPAN TERIMAKASIH}

Dalam kegiatan pengabdian ini, Tim Abdimas mengucapkan terima kasih kepada Lurah Tanjung

$$
\text { Lingkungan dan Kebencanaan }
$$


Duren Selatan, Pengelola dan masyarakat RPTRA Amanah Bunda, pengurus RPTRA di lingkungan kecamatan Petamburan Grogol, Lembaga Pengabdian Masyarakat Universitas Agung Podomoro, mahasiswa Kelas Manajemen Proyek (Rahmad Rivaldi, Agatha Elvanya, Kumala Dewi Siti, Vincent Antonio, Adeline Kurnia) Universitas Agung Podomoro yang telah berperan aktif dalam mensukseskan kegiatan ini.

\section{REFERENSI}

Krismawati. A, (2012), Teknologi Hidroponik Dalam Pemanfaatan Lahan Pekarangan. BPTP. Malang

Roidah, I.S (2014). Pemanfaatan Lahan Dengan menggunakan Sistem Hidroponik, Jurnal Universitas Tulungagung Bonorowo Vol. 1. No.2 Tahun 2014

Undang-Undang Republik Indonesia Nomor 26 tahun 2007 mengenai Penataan Ruang Jakarta. 